\title{
From Clinical Phenotype to Genotypic Modelling: Incidence and Prevalence of Recessive Dystrophic Epidermolysis Bullosa (RDEB) [Corrigendum]
}

Eichstadt S, Tang JY, Solis DC, et al. Clin Cosmet Investig Dermatol. 2019;12:933-942.

There is an error with Table 5 on page 940. The authors have advised due to an error that occurred inadvertently at the time of assembling the tables, Tables 4 and 5 were duplicated. The correct Table 5 is shown below.

The authors apologize for this error.

Table I Demographic Characteristics of the Patients and Caregivers and PD Clinical Characteristics

\begin{tabular}{|l|l|l|}
\hline Phenotype & Number of Cases United States $\mathbf{( 9 5 \% ~ C l )}$ & Number of Cases European Union $(\mathbf{9 5 \%} \mathbf{C l})$ \\
\hline Any RDEB & $12,562(10,080,15,311)$ & $16,290(13,07 I, 19,854)$ \\
\hline RDEB-GO & $12,219(9,824,14,850)$ & $15,845(19,257)$ \\
\hline RDEB-GS & $343(256,460)$ & $445(331,597)$ \\
\hline
\end{tabular}

\section{Publish your work in this journal}

Clinical, Cosmetic and Investigational Dermatology is an international, peer-reviewed, open access, online journal that focuses on the latest clinical and experimental research in all aspects of skin disease and cosmetic interventions. This journal is indexed on CAS.
The manuscript management system is completely online and includes a very quick and fair peer-review system, which is all easy to use. Visit http://www.dovepress.com/testimonials.php to read real quotes from published authors. 